\title{
New insights into the pathogenesis of non-allergic rhinitis
}

\author{
Christine Segboer $^{1 *}$, Wytske Fokkens ${ }^{2}$, Kees Drunen van ${ }^{2}$ \\ From The 10th Symposium of Experimental Rhinology and Immunology of the Nose (SERIN 2015) \\ Stockholm, Sweden. 19-21 February 2015
}

\section{Background}

Effective treatment requires a correct diagnosis, however for different subgroups of chronic rhinitis patients differentiation on a clinical level is complicated. In the case of non-allergic rhinitis (NAR) that represents a wide spectrum of diseases, we are also faced with a missing mechanistic or molecular diagnosis. Here we present an unbiased transcriptomic approach on nasal epithelial cells that assess expression differences between chronic rhinitis subgroups.

\section{Method}

Epithelial cells were obtained from concha inferior biopsies of allergic rhinitis (AR), non-allergic rhinitis (NAR) and healthy controls. Affimetric arrays and were used to determine the expression profiles.

\section{Results}

Comparing subgroups of NAR patients with healthy controls three significant differences were observed related to the activation state of genes. Two classes of genes were significantly up-regulated in non-allergic rhinitis. The first class is related to interferon (INF) signalling and the second class is related to 'epithelial growth factor receptor' (EGFR) signalling pathway. Finally there was a significant difference in cold-induced RNA binding protein (CIRBP) that was activated in NAR and de-activated in healthy. These three path could well be related as CIRBP is able to affect ERK activity downstream of EGFR resulting in increased IFN-levels.

\section{Conclusion}

Assessing differences between chronic rhinitis subgroups using a completely unbiased approach has revealed a novel profile in non-allergic rhinitis. This profile seems

${ }^{1}$ Academic Medical Centre Amsterdam, Amsterdam, Netherlands

Full list of author information is available at the end of the article linked to the way nasal airway epithelial cells respond to cold air. The last observation is very relevant because cold-dry air provocation is the golden standard to assess nasal hyperreactivity. The increased activity of the EGFR and INF-pathways in turn might well explain the symptomatology in these patients.

\section{Authors' details}

${ }^{1}$ Academic Medical Centre Amsterdam, Amsterdam, Netherlands. ${ }^{2}$ Academic Medical Centre Amsterdam, Otolaryngology, Amsterdam, Netherlands.

Published: 26 June 2015

doi:10.1186/2045-7022-5-S4-P1

Cite this article as: Segboer et al:: New insights into the pathogenesis of non-allergic rhinitis. Clinical and Translational Allergy 2015 5(Suppl 4):P1.
Submit your next manuscript to BioMed Central and take full advantage of:

- Convenient online submission

- Thorough peer review

- No space constraints or color figure charges

- Immediate publication on acceptance

- Inclusion in PubMed, CAS, Scopus and Google Scholar

- Research which is freely available for redistribution
() Biomed Central
C Biomed Central

C 2015 Segboer et al. This is an Open Access article distributed under the terms of the Creative Commons Attribution License (http:// creativecommons.org/licenses/by/4.0), which permits unrestricted use, distribution, and reproduction in any medium, provided the original work is properly cited. The Creative Commons Public Domain Dedication waiver (http://creativecommons.org/publicdomain/ zero/1.0/) applies to the data made available in this article, unless otherwise stated. 